\title{
Russia becomes attractive as a source of IP for biotechs
}

Despite Russian efforts to upgrade its intellectual property (IP) legislation, issues related to enforcement of IP protection are still high on the agenda of the working party on Russia's accession to the World Trade Organization (WTO), whose next meeting is likely to be in November. This shift towards increased IP protection, however, has encouraged foreign biotech companies in search of original IP to strike deals with Russian scientists. But such deals often require an intermediary to help foreign biotech adjust to the local business culture and overcome outstanding IP-related hurdles.

Throughout the Soviet era, biological science was almost fully funded by the government. Now, "Science in Russia is much more developed than the country's needs," says Sergei Simaranov, head of Moscow-based TechnoConsult, a consultancy facilitating commercial ventures between Western companies and Russian researchers. Since the fall of the soviet Union, dwindling research budgets have nudged Russian science towards commercialization, but the infrastructure for this within the country has yet to evolve. "It's better to put [Russian technology] on the world stage," Simaranov suggests.

In effect, this spells a range of opportunities for Western companies-both to commercialize technologies within the country, and to develop products for an international market. "There's an enormous amount of technologies that Western companies would like to get their hands on," says Roop Chandwani, CEO of Londonbased TTRBio, which is involved in IP licensing deals with Russian laboratories.

Traditionally, the Moscow-based International Science and Technology Center (ISTC) brokered international technology deals, since its creation in 1992 to convert military research to peaceful ends. $\mathrm{Al}$ though ISTC is managing 400 biotechrelated projects with 100 new ones being added each year, its success can't yet be measured because its commercialization office opened just last year.

Despite Russia's reputation as the Wild West of the business world, a new generation of Western entrepreneurs is increas- ingly willing to take its chances to source IP from the country without ISTC's help. These entrepreneurs are also reassured by the ongoing talks concerning the WTO's Trade Related Intellectual Property rights (TRIPs) agreement, designed to ensure adequate IP protection of their products in Russia. Such talks between Russia and the EU took place last May.

The main incentive for Western companies to look into Russia is financial: the cost of doing R\&D there is as little as $30 \%$ of doing it in Britain, says Chandwani. Also, decades of isolation behind the Iron Curtain has led to some original approaches triggered by the need to find solutions to universal biological problems without the availability of sophisticated equipment. "What attracted us were projects that were innovative and that weren't duplicating what was being done in the West," says Tom Williams, head of the Australian biopharmaceutical development company BioDiem, in Melbourne, which has a number of projects in Russia.

But striking deals with Russian researchers requires navigating the country's immature business climate. The greatest challenge, perhaps, is the lack of clarity around IP ownership. "If you can't define who owns a patent in Russia, someone who challenges it will be able to destroy it in key markets, such as the US," says Ian Harvey, CEO of British Technology Group (BTG) and chair of the UK Intellectual Property Institute, both in London. He says he has encountered technologies claimed by the inventor, the institute, the Russian Academy of Sciences and the government, with no way of untangling the claims.

Compounding the problem, a cultural naiveté around ownership makes scientists more inclined to inadvertently disclose their invention at scientific seminars or during discussion with potential business partners, and less inclined to protect their inventions with nondisclosure agreements. Russian scientists' inexperience makes them simultaneously distrustful of and vulnerable to Western companies that are interested not in longterm collaborative projects, but in pilfering IP, according to Vladimir Khavinson, who directs the Institute of Bioregulation and Gerontology in St. Petersburg.

Despite a modernization of the IP system in Russia, enforcement remains a major issue that will be discussed as part of WTO accession talks. "Everybody has disputes, but the rule of law in Russia is still something to scratch your head on," says Paul Zorner of California biotech Diversa, which is developing several bioindustrial projects with Russian institutes. Already, Russia's transition to a free-market economy in the 1990 s and the country's eagerness to join the WTO has motivated a thorough revision of IP laws over the past decade.

On the books, IP laws differ little from those in Western countries "but in practice, things leave a bit to be desired," says Olga Rodstein, associate attorney at Heller Ehrman White \& McAuliffe in Menlo Park, California. "Western companies cannot rely on [the legal system] for enforcement." Instead, she says, they need to follow local customs and protect their interests informally by establishing relationships with local government officials. Clearly, there is a long way to go before the TRIPs agreementfully protect Russian IP and definitely replace local habits.

Alla Katsnelson, New York 